\title{
Polymorphism in the Exon 11 of Bovine Luteinizing Hormone Receptor Gene and its Association with Service per Conception in Pasundan Cows
}

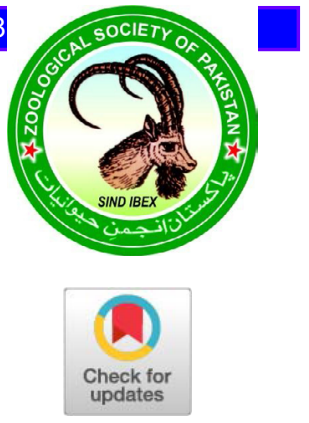

\author{
Syahruddin Said ${ }^{1 *}$, Widya Pintaka Bayu Putra ${ }^{1}$ and Dani Nur Arifin ${ }^{2}$ \\ ${ }^{1}$ Research Center for Biotechnology, Indonesian Institute of Sciences, Bogor-Jakarta Rd. \\ Km. 46, Cibinong, Bogor, West Java, Indonesia 16911 \\ ${ }^{2}$ Department of Animal Sciences, Faculty of Animal Science, Bogor Agricultural \\ University, Agatis Rd., Dramaga Campus, Bogor, West Java, Indonesia 16680
}

\begin{abstract}
A B S T R A C T
Bovine luteinizing hormone receptor (bLHR) gene in mammals is important for several reproduction function such as steroidogenesis, follicular growth, oocytes maturation, ovulation and corpus luteum formation. The aim of this study was to identify the polymorphisms in the exon 11 of bLHR/HhaI gene (SNP g.1553C $>$ T) and its association with service per conception (S/C) of Pasundan cows of West Java, Indonesia. Total of 147 Pasundan cows were used in this study. The PCR-RFLP analysed three genotypes of CC (0.11), CT (0.57) and TT (0.32) were detected in the Pasundan bLHR/HhaI gene with T allele as the dominant allele $(0.61)$. Observed $\left(\mathrm{H}_{\mathrm{o}}\right)$ and expected $\left(\mathrm{H}_{\mathrm{e}}\right)$ heterozygosity had similar values of 0.48 . The polymorphic informative content (PIC) was 0.37 and was of moderate category $(0.25<\mathrm{PIC}<0.50)$. The Chi-square value $\left(\chi^{2}\right)$ was 5.71, which reveals that studied population is under the Hardy-Weinberg equilibrium $\left(\chi^{2}<5.991\right)$. The number of effective allele $\left(n_{e}\right)$ was 1.92. It showed that Pasundan bLHR/ HhaI had two common alleles. Based on the sequencing analysis results of 46 samples, it showed that new mutation at g.1626G $>\mathrm{T}$ was only detected in one individual sample. Polymorphism of bLHR/HhaI gene in the present study was not significantly associated with S/C of Pasundan cows, since the genotype TT of the studied animal was found in the lowest of $\mathrm{S} / \mathrm{C}$ value than other genotype.
\end{abstract}

\begin{tabular}{|c|}
\hline Article Information \\
\hline Received 01 January 2019 \\
\hline Revised 01 April 2020 \\
\hline Accepted 05 May 2020 \\
\hline Available online 25 March 2021 \\
\hline Authors' Contribution \\
\hline $\begin{array}{l}\text { SS conceived and designed the } \\
\text { experiments. DNA performed the } \\
\text { experiments. WPBP analyzed the data. } \\
\text { SS and WPBP wrote the paper. }\end{array}$ \\
\hline Key words \\
\hline $\begin{array}{l}\text { bLHR gene, S/C, SNP, Pasundan } \\
\text { cattle, Polymorphism }\end{array}$ \\
\hline
\end{tabular}

\section{INTRODUCTION}

$\mathrm{P}$ asundan cattle is one of Indonesian native cattle which is well adapted at West Java province of Indonesia. The cattle originated as a result of cross breeding between Bali cattle (Bos javanicus) and Bos indicus cattle (Madura and Ongole) about a hundred years ago (Said et al., 2017). This breeds was decided to be one of Indonesian indigenous cattle since 2014 based on Agriculture Ministry Decree No: 1051/Kpts/SR.120/10/2014 (Anonymous, 2014). Most farmers in West Java believe that the reproductive traits of Pasundan cattle are better than those of crossbred cattle. Unfortunately, there is very limited literature available on reproductive traits of Pasundan cattle. Data from Department of Animal Husbandry of West Java province showed that the reproductive traits of Pasundan cattle are age at first calving 30-40 months, age at sex maturity of bull 25-30 months, gestation length

\footnotetext{
* Corresponding author: syahruddinsaid01@gmail.com 0030-9923/2021/0003-0975 \$ 9.00/0

Copyright 2021 Zoological Society of Pakistan
}

8.5-10 months, age at first oestrus 18-24 months and calving interval 1.1-1.3 years (Anonymous, 2017).

Reproductive traits such as service per conception (S/C) have been neglected in Pasundan cattle. It has been known that reproductive traits have low heritability (Tiezzi et al., 2013). There are many reasons such as genetic, physiology, nutrition and management for reproductive decline in cows (Walsh et al., 2011). Reproductive traits of Pasundan cattle can be improved with good breeding practices management and through molecular selection.

Selection for reproductive traits can be conducted with focus on genetic characterization of the reproductive gene. One of the candidate genes that has potential for selection of reproductive traits in cattle is bovine luteinizing hormone resceptor (bLHR) gene (Nogueira et al., 2010; Hastings et al., 2006) which is located on chromosome 11 and consists of 11 exons (Huhtataniemi, 2000; Marsters et al., 2015). The bLHR gene in livestock is important for secretion of luteinizing hormone (LH) which is important for follicullar development such as ovulation, corpus luteum formation and preimplantation embryonic development (Yu et al., 2012). Previous studies 
showed that $L H R$ gene is associated with polycystic ovary syndrome in humans (Bassiouny et al., 2014), fertility traits in buffalo (Othman and Abdel-Samad, 2013; Sosa et al., 2016), super-ovulation traits and service per conception (S/C) in cattle (Yu et al., 2012; Arslan et al., 2017) and non-gonadal tissues during estrous cycle in sheep (Wang et al., 2012).

Wohlres-Viana et al. (2016) have identified single nucleotide polymorphism (SNP) in the $1^{\text {st }}, 5^{\text {th }}, 6^{\text {th }}, 9^{\text {th }}, 10^{\text {th }}$ and $11^{\text {th }}$ exon of $b L H R$ gene in Gir and Holstein cattle with most of the SNPs in exon 11 in each breed. One of SNPs C/T occured at position 1327 (GenBank: NM 174381.1) or 1553 (GenBank: XM 01969469.1) in the exon 11 of bLHR gene and can be identified with Hha restriction enzyme (Arslan et al., 2017; Omer et al., 2016). Moreover, Wohlres-Viana et al. (2016) reported that the transition mutation at nucleotide position at 1327 or 1553 had amino acid changes from Alanine (Ala) to Valine (Val).

Unfortunately, no study has been conducted to investigate the polymorphism of $b L H R$ gene and its association with reproductive traits in Indonesian native cattle. The objective of the present study was to identify the genetic polymorphism of $b L H R / H h a$ I gene in Pasundan cattle using polymerase chain reaction and restriction fragment length polymorphism (PCR-RFLP) methods and determine its association with $\mathrm{S} / \mathrm{C}$ of Pasundan cattle.

\section{MATERIALS AND METHODS}

\section{Blood samples and DNA extraction}

A total of 147 Pasundan cows from West Java province were used for blood sampling. Blood samples (3-5 mL) were taken from coccygeal vein by using venoject and collected in vaccutainer tubes containing anticoagulant ( $\mathrm{K}_{2}$ EDTA). The blood samples were used for the DNA extraction using the Genomic DNA Mini kit (Geneaid Biotech Ltd., Taiwan) according to the manufactures instruction. The extracted DNA was appropriately labeled and stored at $-20^{\circ} \mathrm{C}$ for PCR and RFLP analyses.

\section{PCR analysis}

PCR was performed in a Mastercyler ${ }^{\circledR}$ gradient machine (Eppendorf, Germany) with a pair of primers Marson et al. (2008) i.e bLHR-F: 5'- CAA ACT GAC AGT CCC CCG CTT T -3' and bLHR-R: 5'- CCT CCG AGC ATG ACT GGA ATG GC -3' to amplify the $b L H R$ gene. These primers were used to amplify the $b L H R$ gene product of $303 \mathrm{bp}$ (Fig. 1). The PCR reagents were as follows: $5.0 \mu \mathrm{L}$ of PCR master mix (Thermo Scientific, USA); each $0.20 \mu \mathrm{L}$ of forward and reverse primers $(200 \mathrm{ng} / \mu \mathrm{L}) ; 2.0 \mu \mathrm{L}$ of DNA samples; and $\mathrm{ddH}_{2} \mathrm{O}$ up to $10 \mu \mathrm{L}$. The PCR program was set up as follows: initial denaturation at $95^{\circ} \mathrm{C}$ for $5 \mathrm{~min}$ followed by 37 cycles and of denaturation at $95^{\circ} \mathrm{C}$ for 45 seconds; annealing at $55^{\circ} \mathrm{C}$ for 45 seconds; initial extension at $72^{\circ} \mathrm{C}$ for 45 seconds and final extension at $72^{\circ} \mathrm{C}$ for $5 \mathrm{~min}$. The PCR product was visualized using $1.0 \%$ agarose gel. The gel was stained with GelRed ${ }^{\mathrm{TM}}$ (Biotium, USA). Total $3.0 \mu \mathrm{L}$ of $100 \mathrm{bp}$ DNA ladder was used as molecular size marker. Electrophoresis $(110 \mathrm{~V} ; 30$ minutes) analysis was used for visualization of PCR product with GBOX Documentation System (Syngene, UK).

\section{RFLP analysis}

The RFLP analysis was done for genotyping of bLHR gene in this study. The reaction mixture consisted of $4.20 \mu \mathrm{L}$ of PCR product, $0.25 \mu \mathrm{L}$ of HhaI restriction enzyme (Promega, USA), $0.10 \mu \mathrm{L}$ acetylated BSA buffer, $1.0 \mu \mathrm{L}$ buffer $10 \mathrm{x}$ and $\mathrm{ddH}_{2} \mathrm{O}$ up to $10 \mu \mathrm{L}$. The mixture reactions was incubated at $37^{\circ} \mathrm{C}$ for $1 \mathrm{~h}$. Digested products were analyzed using electrophoresis $(110 \mathrm{~V} ; 1 \mathrm{~h})$ on $2.0 \%$ agarose gel with $3.0 \mu \mathrm{L}$ of $100 \mathrm{bp}$ DNA ladder. The digested product was stained with GelRed ${ }^{\mathrm{TM}}$ and captured with GBOX Documentation System. Three genotypes of CC (155 bp and 148 bp), CT (303 bp, 155 bp and 148 bp) and TT (303 bp) were identified based on sequence (GenBank: XM_01969469.1) analysis. However, DNA fragment of $148 \bar{b}$ p was not detected in this study because the distance between another fragment was very small (7 $\mathrm{bp}$ ), and hence this fragment was not clearly separated.

\section{Sequencing analysis}

The DNA sequencing was performed using 46 samples of animal. Total of $30 \mu \mathrm{l}$ PCR product of each sample were used for sequencing analysis. The PCR products of individual cattle were sequenced using ABI Prims 3100-Avant Genetic Analyzer in the $1^{\text {st }}$ BASE Laboratory, Malaysia. The Pasundan $b L H R$ gene sequences were aligned and compared with the Bos indicus bLHR gene (GenBank: XM_01969469.1) using MEGA ver 6.0 programs (Tamura et al., 2013).

\section{Data analysis}

The genotype data obtained in this study were used for calculating genetic diversity parameters such as genotype and allele frequencies (Nei and Kumar, 2000), expected and observed heterozygosity (Weir, 1996), polymorphic informative content (Hildebrand et al., 1992; Shete et al., 2000), number of effective allele (Nei and Tajima, 1981) and Chi-square value (Kaps and Lamberson, 2004). Morever, data of service per conception (S/C) were analyzed by applying linear mixed model as follows:

$$
\mathrm{Y}_{\mathrm{i}}=\mu+\mathrm{G}_{\mathrm{i}}+\mathrm{e}_{\mathrm{i}}
$$

Where, $Y_{i}$ is the dependent variable $(\mathrm{S} / \mathrm{C}), \mu$ is the 
overall mean, $\mathrm{G}_{\mathrm{i}}$ is the fixed effect of $\mathrm{i}^{\text {th }}$ genotype (CC, CT and TT) and $\mathrm{e}_{\mathrm{i}}$ is the random residual effect.

\section{RESULTS AND DISCUSSION}

The amplified DNA bLHR gene (amplicons) product showed a single of band $303 \mathrm{bp}$ (Fig. 2). The length of amplicons are similar to sequence target from GenBank reference (Fig. 1). The visualization of PCR-RFLP results showed that three genotypes of $\mathrm{CC}$, $\mathrm{CT}$ and TT were clearly observed (Fig. 3). Two alleles of $\mathrm{C}(0.39)$ and $\mathrm{T}(0.61)$ were identified in the $b L H R$ gene in this study (Table I). Previous studies reported that high $\mathrm{C}$ allele frequencies were observed in Bos taurus breeds such as East Anatolian Red (0.75), South Anatolian Red (0.70), Turkish Grey (0.71), Anatolian Black (0.61), Zavot (0.69), Turkish Holstein (0.99) and 0.91 for Japanese Holstein (Arslan et al., 2015, 2017; Shirasuna et al., 2011). Several studies reported that high $\mathrm{T}$ allele frequencies occured in Bos indicus breeds such as Gir (0.77), Kenana (0.55) and 0.58 for Erashy (Wohlres-Viana et al., 2016; Omer et al., 2016). Other studies also reported that high $\mathrm{C}$ allele frequencies were reported in Bos indicus breeds of Butana (0.56) and 0.58 for composite breed of 50\% Zebu x 50\% British (Omer et al., 2016; Marson et al., 2008). They concluded that most of Bos indicus breeds had higher T allele frequency than Bos taurus breeds.

\section{8} 1441 gcagacttct gcatggggct ctacctgctg ctcattgcct cagtcgatgc ccagaccaaa 1501 ggccagtatt acaaccatgc catagactgg cagacaggga gtgggtgcag cg Vyggctggc 1561 tttttcactg tgtttgcaag tgaactctct gtctacaccc tcacagtcat cacactagaa 1621 agatggcaca ccatcaccta tgctattcaa ctggaccaaa agctgcgact gaaacatgce 1681 attccagtca tgctcggagg

Fig. 1. Primer position (underline) and HhaI restriction site (5'...GCG ||T...3') in the bLHR gene (Bos indicus) according to GenBank: XM_01969469.1 with $\mathrm{y}=\mathrm{C} / \mathrm{T}$.

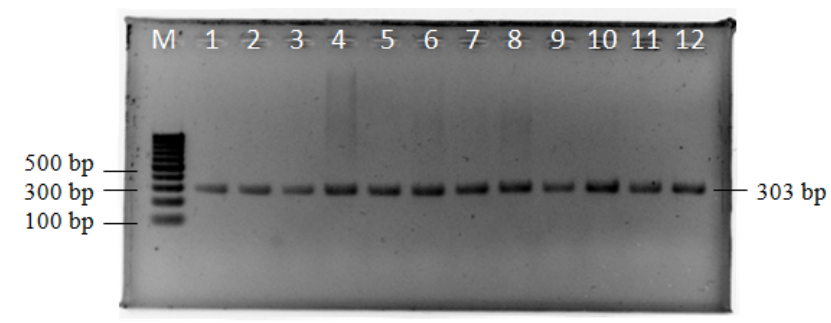

Fig. 2. The amplification product of $b L H R$ gene on $1 \%$ agarose gel. M, marker (DNA ladder $100 \mathrm{bp}$ ); lanes 1-12, number of sample.

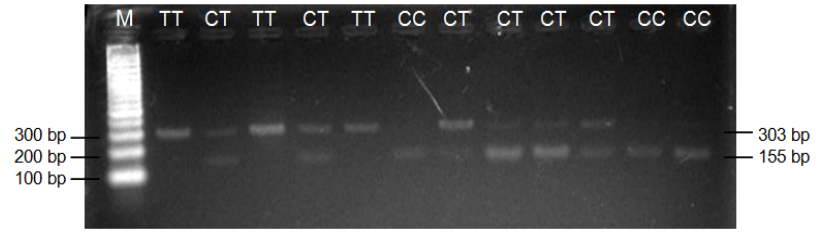

Fig. 3. The fragments of $b L H R$ gene using PCR-RFLP method with $H$ haI restriction enzyme on $2 \%$ agarose gel showed three genotypes of CC (155 bp), CT (303 bp and $155 \mathrm{bp}$ ) and TT (303 bp). M, marker (DNA ladder $100 \mathrm{bp}$ ).
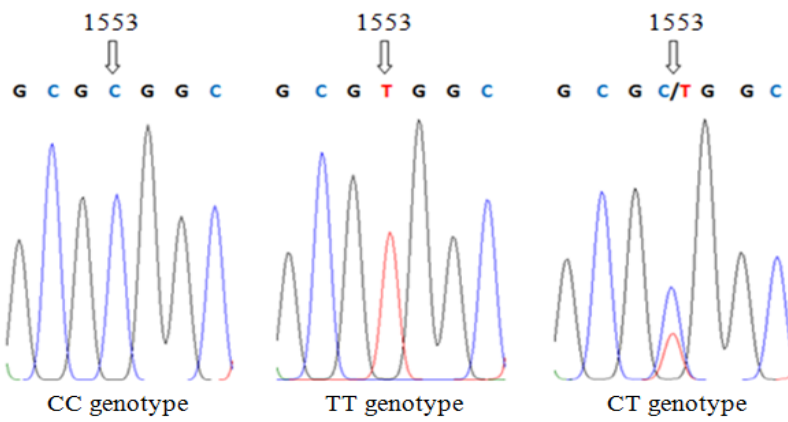

Fig. 4. Part of chromatogram showing characteristics of SNP at $\mathrm{g} .1553 \mathrm{C}>\mathrm{T}$ in the exon 11 of Pasundan $b L H R$ gene.

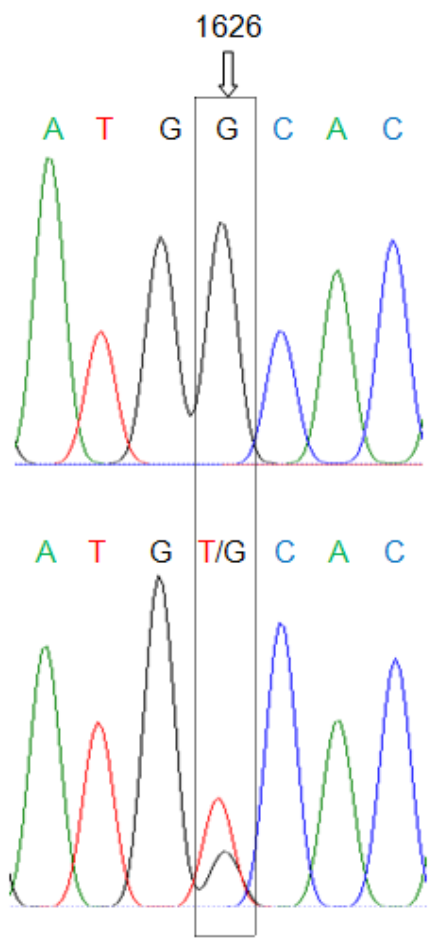

Fig. 5. Part of chromatogram of new SNP at g. $1626 \mathrm{G}>\mathrm{T}$ in Pasundan $b L H R$ gene in one individual sample. 
The observed $\left(\mathrm{H}_{\mathrm{o}}\right)$ and expected $\left(\mathrm{H}_{\mathrm{e}}\right)$ values were similar (0.48) which means that population used in this study was in genetic equilibrium (Table I). The Chi-square $\left(\chi^{2}\right)$ test value in this study (5.71) was lower than $\chi^{2}$ table (5.99) and indicated that the population studied was under Hardy-Weinberg equilibrium. The PIC value in this study was 0.37. According to Selvaggi and Dario (2011), the PIC values consisted of three categories low (PIC $\leq 0.25$ ), moderate $(0.25 \leq \mathrm{PIC} \leq 0.50)$ and high $(\mathrm{PIC} \geq 0.50)$. In diploid gene, moderate PIC value can be used as an indicator of molecular selection conducted based on the polymorphism information. The number of effective allele $\left(n_{e}\right)$ in this study was 1.92 and explained that $\mathrm{C}$ and $\mathrm{T}$ alleles are common alleles in $b L H R$ gene of Pasundan cattle with $\mathrm{T}$ allele as the dominant allele.

Table I. The statistical analysis for $b L H R / H h a I$ gene polymorphism in Pasundan cattle.

\begin{tabular}{lllllllllll}
\hline Genotype frequency (N) & $\begin{array}{l}\text { Allele } \\
\text { frequency }\end{array}$ & $\mathbf{H}_{\mathrm{e}}$ & $\mathbf{H}_{\mathrm{o}}$ & PIC & $\mathbf{n}_{\mathrm{e}}$ & $\chi^{2}$ \\
\cline { 1 - 3 } & $\mathbf{C T}$ & TT & $\mathbf{C}$ & $\mathbf{T}$ & & & & & \\
\hline $0.11(16)$ & $0.57(84)$ & $0.32(47)$ & 0.39 & 0.61 & 0.48 & 0.48 & 0.37 & 1.92 & $5.71^{*}$
\end{tabular}

$\mathrm{N}$, number of observation; $\mathrm{H}_{\mathrm{o}}$, observed heterrozigosity; $\mathrm{H}_{\mathrm{e}}$, observed heterozigosity; PIC, polymorphism informative content; $\mathrm{n}_{\mathrm{e}}$, number of effective allele; $\chi^{2}$, Chi-square value; *, under Hardy-Weinberg equilibrium $\left(\chi_{2}^{2} ;_{0.05}=5.991\right)$.

Table II. Association of $b L H R / H h a I$ gene polymorphism with service per conception $(\mathrm{S} / \mathrm{C})$ in Pasundan cows.

\begin{tabular}{lll}
\hline Genotype & $\mathbf{N}$ & $\mathbf{S} / \mathbf{C}$ \\
\hline CC & 7 & $2.57 \pm 1.51$ \\
CT & 23 & $2.39 \pm 1.44$ \\
TT & 5 & $2.00 \pm 0.71$ \\
\hline
\end{tabular}

$\mathrm{N}$, number of observation.

The sequencing results showed that the transition mutation occured at position g. 1553C $>\mathrm{T}$ in the exon 11 of $b L H R$ gene in Pasundan cattle (Fig. 4). Moreover, the novel SNP at g. 1626G $>$ T occured only in one individual sample of Pasundan cow (Fig. 5) and has never been reported previously. The rare $\mathrm{T}$ allele in the SNP at $\mathrm{g} .1626 \mathrm{G}>\mathrm{T}$ reveals that the genetic drift occured in this allele. Preliminary study with 50 Pasundan cows showed that $\mathrm{SNP}$ at $\mathrm{g} .1553 \mathrm{C}>\mathrm{T}$ in the $b L H R$ gene was not associated with S/C (Table II). Genotype of TT in this study had the lowest $\mathrm{S} / \mathrm{C}$ value than other genotypes. Arslan et al. (2017) reported that most of the genotype $\mathrm{CC}$ in Friesian Holstein cows had low $\mathrm{S} / \mathrm{C}$ value. However, in this study, animals with CC genotype had the highest S/C compareed with other genotypes. The T allele in the $b L H R / H h a \mathrm{I}$ gene may be influencing the reproductive traits of Bos indicus cattle, including Pasundan cows.

\section{CONCLUSION}

Bovine luteinizing hormone receptor (bLHR/HhaI) gene in the Pasundan cattle had moderate polymorphic level $(\mathrm{PIC}=0.37)$ and can be used as molecular selection in the breeding program. The T allele in $b L H R / H h a \mathrm{I}$ gene of Pasundan herds was higher than $\mathrm{C}$ allele and similar to the previous studies in Bos indicus breeds. This study shows that polymorphism of $b L H R / H h a \mathrm{I}$ gene was not significantly associated to $\mathrm{S} / \mathrm{C}$ in Pasundan cows. Further study is needed to confirm the effect of SNP at $\mathrm{g} .1553 \mathrm{C}>\mathrm{T}$ associated with reproductive traits in a large number of samples as genetic markers.

\section{ACKNOWLEDGMENT}

Authors thank Bureau of Research and Development for the Region of West Java province ( $\mathrm{BP}_{2} \mathrm{D}$ Jawa Barat) for financial support and the Pasundan Breeding Center (BPPIBT-SP Ciamis, Jawa Barat) for blood sample collection and record data support. Authors would like to thank Novi Cahya Lestari for her technical assistance and to all members of Animal Research Group at the Research Center for Biotechnology of the Indonesian Institute of Sciences.

Statement of conflict of interest

The authors have declared no conflict of interest.

\section{REFERENCES}

Anonymous, 2014. Agriculture Ministry Decree No.1051/Kpts/SR.120/10/2014 about establishment of Pasundan cattle breed. https://www.dkpp. jabarprov.go.id. (article in Indonesian).

Anonymous, 2017. Characteristics of Pasundan cattle. Department of Animal Hosbandry of West Java. https://www.jabar.litbang.pertnian.go.id. (article in Indonesian)

Arslan, K., Akyuz, B. and Agaoglu, O.K., 2015. Investigation of STAT5A, FSH and LHR genes polymorphisms in Turkish indigenous breeds (East Anatolian Red, South Anatolian Red, Turkish Grey, Anatolian Black and Zavot). Russian J. Genet., 51: 1088-1095. https://doi.org/10.1134/ S1022795415110022

Arslan, K., Akyuz, B., Akcay, A., Ilgar, E.G., Macun, H.C. and Cinar, M.U., 2017. Association of number 
of artificial inseminations per pregnancy in Holstein dairy cows with polymorphism in luteinizing hormone receptor and follicle stimulating hormone receptor genes. Slov. Vet. Res., 54: 91-98.

Basiouny, Y.A., Rabie, W.A., Hassan, A.A. and Darwish, R.K., 2014. Association of the luteinizing hormone/choriogonadotropin receptor gene polymorphism with polycystic ovary syndrome. Gynecol. Endocrinol., 30: 428-430. https://doi.org /10.3109/09513590.2014.895982

Hastings, N., Donn, S., Derecka, K., Flint, A.P. and Woolliams, J.A., 2006. Polymorphisms within the coding region of the bovine luteinizing hormone receptor gene and their association with fertility traits. Anim. Genet., 37: 583-585. https://doi. org/10.1111/j.1365-2052.2006.01532.x

Hildebrand, C.E., Torney, D.C. and Wagner, R.P., 1992. Informativeness of polymorphic DNA markers. Los Alamos Sci., 20: 100-102.

Huhtaniemi, I., 2000. Mutations of gonadotrophin and gonadotrophin receptor genes: what do they teach us about reproductive physiology? J. Reprod. Fertil., 119: 173-186. https://doi.org/10.1530/ reprod/119.2.173

Kaps, M. and Lamberson, W.R., 2004. Biostatistics for animal sciences. CABI Publishing; London (UK). pp. 562. https://doi. org/10.1079/9780851998206.0000

Marson, E.P., Ferraz, J.B.S., Meirelles, F.V., Balieiro, J.C.C. and Eler, J.P., 2008. Effects of polymorphisms of LHR and FSHR genes on sexual precocity in a Bos taurus x Bos indicus beef composite population. Genet. mol. Res., 7: 243-251. https:// doi.org/10.4238/vol7-1 gmr418

Marsters, P., Kendall, N.R. and Campbell, B.K., 2015. Pre-translational regulation of luteinizing hormone receptor in follicular somatic cells of cattle. Anim. Reprod. Sci., 163: 63-74. https://doi.org/10.1016/j. anireprosci.2015.09.019

Nei, M. and Tajima, F., 1981. Genetic drift and estimation of effective population size. Genetics, 98: 625-640.

Nei, M. and Kumar, S., 2000. Molecular evolution and phylogenetics. Oxford University Press, New York (USA). pp. 333.

Nougueira, M.F.G., Fernandes, P., Ereno, R.L., Simoes, R.A.L., Junior, J.B. and Barros, C.M., 2010. Luteinizing hormone receptor (LHR): basic concepts in cattle and other mammals. Anim. Reprod., 7: 51-64.

Omer, N.N., Gornas, N., Rahmatalla, S.A. and Ahmed, M.K.A., 2016. Genetic characterization of indigenous Sudanese cattle using FSHR and LHR genes. Am. Sci. Res. J. Eng. Technol. Sci., 24: 1-9.

Othman, O.E. and Abdel-Samad, M.F., 2013. RFL polymorphism of three fertility genes in Egyptian buffalo. J. appl. Biol. Sci., 7: 94-101.

Said, S., Putra, W.P.B., Anwar, S., Agung, P.P. and Yuhani, H., 2017. Phenotypic, morphometric characterization and population structure of Pasundan cows at West Java, Indonesia. Biodiversitas, 18: 1638-1645.

Selvaggi, M. and Dario, C., 2011. Analysis of two Pit-1 gene polymorphisms: Single nucleotide polymorphisms (SNPs) distribution patterns in Podolica cattle breed. Afri. J. Biotechnol., 10: 11360-11364.

Shete, S., Tiwari, H. and Elston, R.C., 2000. On estimating the heterozygosity and polymorphic information content. Theor. Popul. Biol., 57: 265271. https://doi.org/10.1006/tpbi.2000.1452

Shirasuna, K., Kawashima, C., Murayama, C., Aoki, Y., Masuda, Y., Kida, K., Matsui, M., Shimizu, T. and Miyamoto, A., 2011. Relationships between the first ovulation postpartum and polymorphism in genes relating to function of immunity, metabolism and reproduction in high-producing dairy cows. $J$. Reprod. Dev., 57: 135-142. https://doi.org/10.1262/ jrd.10-100T

Sosa, A.S.A., Mahmoud, K.G.M., Kandiel, M.M.M., Eldebaky, H.A.A., Nawito, M.F. and Abou ElRoos, M.E.A., 2016. Genetic polymorphism of luteinizing hormone receptor gene in relation to fertility of Egyptian buffalo. Biol. Technol., 12: $1-10$.

Tamura, K., Stecher, G., Peterson, D., Filipski, A. and Kumar, S., 2013. MEGA6: Molecular evolutionary genetic analysis version 6.0. Mol. Biol. Evol., 30: 2725-2729. https://doi.org/10.1093/molbev/mst197

Tiezzi, F., Pretto, D., De Marchi, M. and Penasa, M., 2013. Heritability and repeatability of milk coagulation properties predicted by mid-infrared spectroscopy during routine data recording, and their relationships with milk yield and quality traits. Animal, 7: 1592-1599. https://doi.org/10.1017/ S1751731113001195

Wang, L.H., Zhang, W., Gao, Q.X. and Wang, F., 2012. Expression of the luteinizing hormone receptor (LHR) gene in ovine non-gonadal tissues during estrous cycle. Genet. mol. Res., 11: 3766-3780. https://doi.org/10.4238/2012.October.15.8

Walsh, S.W., Wlliam, E.J. and Evans, A.C.O., 2011. A review of the causes of poor fertilty in high milk producing dairy cows. Anim. Reprod. 
Sci., 123: 127-138. https://doi.org/10.1016/j. anireprosci.2010.12.001

Weir, B.S., 1996. Genetic data analysis: Method for discrete population genetic data. $2^{\text {nd }}$ Ed. Sinauer Associated; Sunderland (USA). pp. 445.

Wohlres-Viana, S., Arashiro, E.K.N., Reis, D.R.L., Fernandes, L.E., Peixodo, M.G.C.D., Machado, M.A. and Viana, J.H.M., 2016. Polymorphisms and alternative splicing of the luteinizing hormone receptor of dairy cattle. Genet. mol. Res., 15: 1-12. https://doi.org/10.4238/gmr.15027046

Yu, Y., Pang, Y., Zhao, H., Xu, X., Wu, Z., An, L. and Tian, J., 2012. Association of a missense mutation in the luteinizing hormone / choriogonadotropin receptor gene (LHCGR) with superovulation traits in Chinese Holstein heifers. J. Anim. Sci. Biotechnol., 3: 1-5. https://doi.org/10.1186/20491891-3-35 